\title{
PRODUKSI ANTOSIANIN DARI DAUN MIANA (Plectranthus scutellarioides) SEBAGAI PEWARNA ALAMI
}

\section{[Anthocyanin Production From Miana Leaves (Plectranthus scutellarioides) as Natural Pigment]}

\author{
Dhanang Puspita1)*, Yosephine Diana Tjahyono1), Yunius Samalukang²), Binerd Anthon Im \\ Toy2), Norson Willem Totoda ${ }^{3)}$ \\ 1) Teknologi Pangan, Universitas Kristen Satya Wacana, Salatiga \\ 2) Magister Biologi, Universitas Kristen Satya Wacana, Salatiga \\ 3) Carotenoid Antioxidant Research Center, Universitas Kristen Satya Wacana, Salatiga \\ *email: dhanang.puspita@staff.uksw.edu
}

\begin{abstract}
Miana (Coleus scutellaroides) is an ornamental plant of single leaf a purple color. The purple color found from miana leaves is an indicator of the presence of anthocyanin pigments. Anthocyanin from miana leaves can be utilized as a natural pigment for various staining purposes especially in the food industry, anthocyanin harvesting on miana leaves can be done at any time and does not depend on the season due to its abundant availability in nature. The aims of this study were to isolate, identify, and microencapsulated anthocyanin pigments of miana leaves. The result, pigment extracted from miana leaves had characteristic of purple color and having maximum absorbance at wavelength $529 \mathrm{~nm}$, suspected as anthocyanin derivative (cyanidin-3-routosida). The total microcapsulated anthocyanim was $0.149542 \mathrm{mg} / \mathrm{g}$. Thermostability of encapsulated anthocyanin pigment from miana leaves stable with heat exposure temperature $100^{\circ} \mathrm{C}$ up to 60 minutes. Based on those collected information, encapsulated miana leaves pigment could be used as an additional natural coloring in food industries.
\end{abstract}

Keywords: anthocyanin, miana, microencapsulation, pigment, thermostability.

\section{ABSTRAK}

Miana (Coleus scutellaroides) termasuk ke dalam tanaman hias yang berdaun tunggal dan berwarna ungu. Warna ungu yang terdapat pada daun miana adalah indikator keberadaan pigmen antosianin.Pemanfaatan daun miana sebagai sumber antosianin dapat dimanfaatkan sebagai pigmen alami untuk berbagai keperluan pewarna terutama dalam industri pangan, pemanenan antosianin pada daun miana dapat dilakukan setiap saat dan tidak bergantung pada musim dikarenakan ketersediannya yang selalu melimpah di alam.Tujuan dari penelitian ini adalah untuk mengisolasi, mengidentifikasi, dan mikroenkapsulasi pigmen antosianin dari daun miana.Berdasarkan hasil analisis didapati bahwa ekstrak pigmen daun miana memiliki karakteristik warna nampak ungu dan serapan maksimum absorbansinya berada pada panjang gelombang $529 \mathrm{~nm}$, pigmen diduga sebagai turunan antosianin yaitu sianidin-3-rutinosida.Total antosianim yang sudah dimikroenkapsulasi sebesar $0.149542 \mathrm{mg} / \mathrm{g}$. Dari hasil uji thermostabilitas pigmen terenkapsulasi maltodekstrin, stabilitas pigmen antosianin dari daun miana cenderung stabil dengan adanya pemaparan panas suhu $100^{\circ} \mathrm{C}$ hingga 60 menit.Berdasarkan hasil dan pengujian, pigmen daun miana terenkapsulasi dapat menjadi pertimbangan produk untuk digunakan sebagai bahan tambahan pewarna dalam industri pangan.

Kata kunci: antosianin, miana, mikroenkapsulasi, pigmen, termostabilitas.

\section{PENDAHULUAN}

Miana atau dikenal juga sebagai tumbuhan iler adalah daun pucuk yang memiliki nama ilmiah Coleus scutellaroides termasuk dalam tanaman herba atau perdu. Miana dapat dikembang biakan dengan biji atau pun stek, sehingga memudahkan dalam perbanyakan penanaman. Pemanenan daun dapat dilakukan setiap saat tanpa mengenal musim dan bisa diperoleh setiap saat. Tumbuhan ini banyak tumbuh liar ditempat yang lembab dan terbuka, seperti ditepi selokan dan di pematang sawah, dibeberapa daerah juga digunakan sebagai sayuran maupun obat (Anonim, 2004).

Daun miana berwarna ungu kecoklatan sampai ungu kehitaman dan ada beberapa yang bagian pinggirnya bercorak hijau atau kuning. Warna yang nampak pada daun miana merupakan atribut visual yang timbul akibat pemantulan cahaya. Pigmen yangbertanggung jawab terhadap munculnya warna ungu pada daun miana adalah antosianin. Variasi warna daun pada masing-masing varietas dipengaruhi oleh pigmen yang terakumulasi didalamnya, misalnya corak hijau yang nampak pada daun menandakan adanya akumulasi pigmen klorofil. Warna ungu pekat pada seluruh permukaan daun yang nampak pada daun miana disebabkan oleh tingginya kandungan antosianin (Nguyen \& Cin, 2009).

Antosianin adalah pigmen alami yang larut dalam air yang diturunkan dari cabang biosintesis flavanoid (Nguyen dan Cin, 2009). 
Senyawa antosianin bersifat amfoter yaitu memiliki kemampuan untuk bereaksi baik dengan asam maupun dengan basa. Dalam kondisi asam antosianin akan berwarna merah tua, dan pada media basa berubah menjadi ungu dan biru. Di dalam daun miana, antosianin terekspresi dalam warna ungu. Pemanfaatan antosianin dalam daun miana dapat menjawab kebutuhan industri pangan terhadap permintaan pewarna yang bersifat non toksik dan aman. Pigmen alami dalam daun miana dapat menggantikan penggunaan pigmen sintetik yangmemiliki dampak negatif bagi kesehatan manusia dan lingkungan. Pigmen sintetiksusah terurai di alam dan ketika dikonsumsi dapat menyebabkan keracunan dan berpotensi menjadi kanker (Winarti dkk, 2008).

Antosianin pada daun miana sebagai salah satu potensi penghasil pigmen alamiyang memiliki beberapa keuntungan yaitu; proses produksi pigmen yang relatif mudah, murah dan aman. Mudah dan murah karena bahannya selalu tersedia di alam dan melimpah, aman karena sifatnya non toksik dan dapat diekstraksi menggunakan bahan yang tidak berbahaya untuk kesehatan manusia maupun keseimbangan lingkungan alam. Antosianin dapat diekstrak dengan menggunakan air suling.

Proses pengkristalan atau enkapsulasi antosianin bertujuan untuk mengurangi pengaruh luar lingkungan yang mungkin berdampak buruk bagi pigmen. Enkapsulasi adalah salah satu cara yang efisien untuk memasukan suatu senyawa kedalam sebuah produk, didefinisikan juga sebagai proses untuk menjebak zat aktif didalam bahan penyalut (Tensiska dkk, 2012). Enkapsulasi pigmen menjadikan produk menjadi berupa kristal atau serbuk sehingga mempermudah dalam proses penyimpanannya Antosianin yang sudah dimikroenkapsulasi diharapkan bisa memberikan nilai tambah terkhusus pada teknis pemanfaatannya.

Proses pengkristalan antosianin dilakukan dengan menggunakan maltodekstrin yang merupakan bahan tambahan pangan yang aman. Maltodekstrin adalah padatan dekstrosa yang dapat digunakan sebagai bahan penyalut dengan kelarutan airnya yang tinggi, viskositas rendah, kadar gula rendah, dan kelarutannya tidak berwarna. Sifat-sifat tersebut merupakan prasyarat bahan penyalut yang paling umum digunakan dalam mikroenkapsulasi (Mahdavi dkk., 2016). Tujuan dari penelitian ini adalah untuk mengisolasi, mengidentifikasi, memproduksi dan menguji antosianin dari daun miana sebagai penghasil pigmen alami. Dari hasil penelitian ini diharapkan memberikan informasi tentang produksi pigmen alami dari daun miana untuk memenuhi kebutuhan pigmen alami dipasaran.

\section{METODOLOGI}

\section{Ekstraksi Daun Miana}

Sebanyak $200 \mathrm{gr}$ daun miama ditumbuk dalam mortar hingga halus lalu dimaserasi dengan akuades yang telah ditambahkan asam asetat glasial 0,1\% sebanyak $500 \mathrm{ml}$ secara bertahap hingga terekstraksi secara maksimal. Ekstraksi daun miana kemudian disentrifugasi selama 10 menit dengan kecepatan 4.000 RPM hingga diperoleh pelet dan supernatan. Supernatan kemudian disimpan untuk proses analisis dan pengkristalan pigmen.

\section{Kristalisasi Pigmen}

Sebanyak $200 \mathrm{ml}$ supernatan pigmen daun miana dicampur dengan maltodekstrin sebanyak $20 \mathrm{gr}(10 \%)$. Campuran keduanya kemudian dimasukan dalam tabung kolf dan selanjutnya dilakukan penguapan dengan vacuum rotary evaporator. Suhu yang digunakan dalam penguapan ini adalah $60^{\circ} \mathrm{C}$. Setelah 90 menit akan terbentuk kristal-kristal dan kemudian dilakukan penggerusan dengan mortar dan dilakukan pengayakan. Kristal pigmen yang sudah dihaluskan disimpan dalam botol dan ditutup rapat dalam lemari pendingin.

\section{Analisis Pigmen}

Analisis pertama dengan menggunakan spektrofotometer UV-vis untuk pemindaian pigmen. Sebanyak $4 \mathrm{ml}$ sampel yang terdiri dari ekstrak murni, kristal pigmen yang sudah dilarutkan dan dipanaskan selama 0, 10, 20, 30, 40, 50, dan 60 menit dipindai pada panjang gelombang $200-800 \mathrm{~nm}$. Hasil pemindaian kemudian diolah dengan menggunakan perangkat lunak Origin ver.9. Analisis kedua menggunakan KLT (kromatografi lapis tipis), yakni dengan menotolkan supernatan yang telah dipekatkan. Dalam KLT digunakan 3 eluen yakni akuades, aseton, dan heksan yang dilakukan secara terpisah dan masing-masing selama 15 menit. Hasil dari KLT dihitung RF berdasarkan fraksi-fraksi warna yang terbentuk.

\section{Uji Termostabilitas}

Kristal pigmen sebanyak 10\% dilarutkan dalam akuades. Kristal yang sudah dilarutkan kemudian dipanaskan sampai di titik 
didih air $\left(100^{\circ} \mathrm{C}\right)$. Setiap kelipatan 10 menit yakni mulai dari $0,10,20,30,40,50$, dan 60 menit dilakukan sampling untuk selanjutnya dilakukan analisis.

Penghitungan total antosianin (TA) dilakukan dengan rumus sebagai berikut:

$T A=\frac{(\text { Abs530 }-0,25 . \text { Abs657) } x \text { total volume extract }(m l)}{\text { massa sampel }(g r)}$ massa sampel $(\mathrm{gr})$

\section{HASIL DAN PEMBAHASAN}

\section{Miana, Sumber Pigmen Antosianin}

Penampakan visual memengaruhi kesan serta persepsi. Warna merupakan salah satu atribut visual yang timbul dari adanya pemantulan cahaya. Zat warna atau pigmen tersedia di alam, dapat ditemukan pada tumbuhan maupun hewan. Pigmen dapat pula dihasilkan dengan mereaksikan zat-zat kimia, namun penggunaan pigmen yang bersumber dari reaksi kimia buatan memiliki efek negatif bagi kesehatan dan lingkungan. Pigmen sintetik dapat menyebabkan keracunan dan berpotensi menyebabkan kanker, berbeda dengan pigmen alami yang diklaim bersifat non toksik, non karsinogenik dan mudah teruraidi alam. Mengetahui berbagai dampak negatif dari penggunaan pigmen sintetik menjadikan dasar berpikir untuk mengeksplorasi dan mengembangkan produk pewarna yang bersumber dari alam.

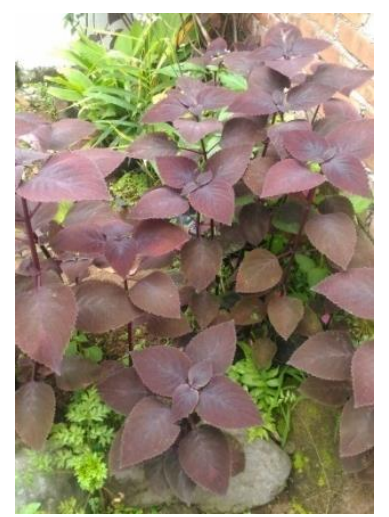

Gambar 1. Daun Miana

Daun miana (Gambar 1) keberadaannya melimpah dan selalu tersedia di alam tanpa mengenal musim. Warna ungu yang nampak menandakan keberadaan pigmen antosianin. Antosianin adalah turunan struktur aromatik tunggal, yaitu sianidin, dengan penambahan atau pengurangan dari gugus hidroksil, metilasi dan glikosilasi (Harborne, 2005).

Pigmen antosianin dapat diekstrak menggunakan berbagi jenis pelarut yang bersifat polar. Pigmen antosianin dalam daun miana diekstrak menggunakan akuades, pemilihan pelarut berdasarkan pertimbangan nilai ekonomis dan toksisitas. Akuades memiliki harga yang murah dan bersifat non toksik sehingga baik digunakan sebagai pelarut dalam produksi pigmenuntuk suplai pewarna industri pangan. Ekstrak pigmen daun miana seperti yang ditunjukkan pada Gambar 2 nampak berwarna ungu. Senyawa antosianin bersifat amfoter, pada $\mathrm{pH}$ rendah $(1-2)$ bentuk dominan antosianin adalah kation flaviliumdan nampak berwarna merah tua, menuju $\mathrm{pH}$ netral menjadi berbentuk karbinol dan sebagian menjadi kuinonoidal sehingga nampak berwarna biru-ungu dan akan berwarna biru jika dalam kondisi basa (Gross, 1987).

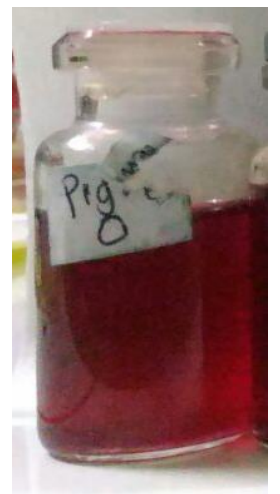

Gambar 2. Ekstrak Pigmen

\section{Analisis Antosianin}

Pembacaan pola spektra pada spektrofotometer UV-vis dilakukan untuk melihat absorbansi maksimal sampel, selain itu juga dapat digunakan untuk mengetahui konsentrasi total pigmen dalam sampel. Pola spektra ekstrak daun miana tergambarkan dalam Gambar 3. Pada pola spektra tesebut terlihat bahwa puncak serapan maksimal berada pada $529 \mathrm{~nm}$, diduga bahwa pigmen adalah sianidin-3-rutinosida. Berdasarkan literature, ada sekitar 17 antosianidin yang ditemukan di alam, tapi hanya enam (sianidin, delphinidin, petunidin, peonidin, pelargonidin, dan malvidin) yang paling sering ditemukan (Miguel, 2011). Antosianin memiliki titik puncak serapan $520 \mathrm{~nm}$ (perlargonidin), $535 \mathrm{~nm}$ (cyanidin), dan $546 \mathrm{~nm}$ (delphinidin) (Gross, 1987). 


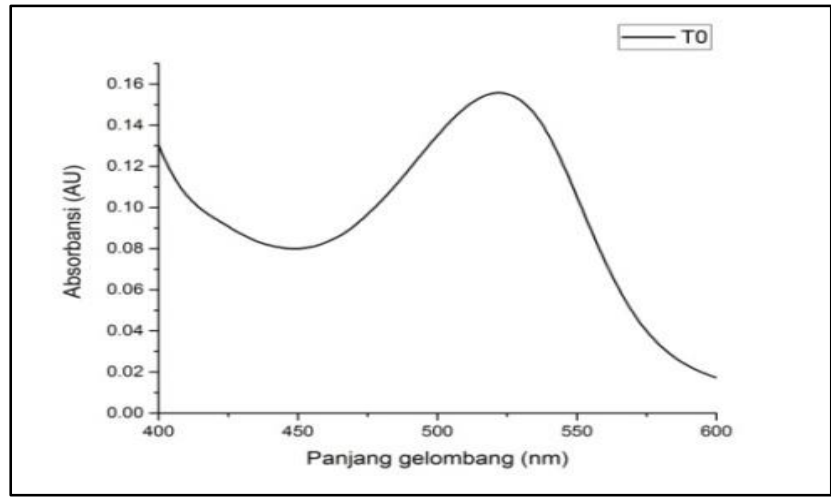

Gambar 3. Pola Spektra Pigmen

Dari hasil KLT pada Tabel 1 terlihat dua fraksi pigmen. Fraksi pigmen terpisah berdasarkan berat molekulnya.Pigmen yang nilai Rf-nya tinggi, artinya memilik berat molekul yang lebih berat, begitu pula sebaliknya. Perbedaan berat molekul antar pigmen dalam ekstrak daun miana menyebabkan terbentuk dua fraksi pigmen hijau dan ungu. Fraksi pigmen hijau diduga klorofil dan fraksi pigmen ungu adalah antosianin.

Tabel 1. Hasil uji KLT

\begin{tabular}{cclc}
\hline KLT & \multicolumn{1}{c}{ Eluen } & Warna & Rf \\
\hline & Heksan & Hijau & $5 \mathrm{~cm}$ \\
Etanol & & \\
\cline { 3 - 4 } & Aquades & & \\
\cline { 3 - 4 } & & & \\
& & & \\
& & & \\
& & & \\
& & & \\
& & & \\
\end{tabular}

\section{Produk Pigmen}

\section{(Mikroenkapsulasi \\ dan Uji Thermostabilitas)}

Enkapsulasi merupakan sebuah teknik yang dilakukan untuk mengubah bentuk bahan dan melindunginya terhadap pengaruh faktor lingkungan. Mikroenkapsulasi adalah suatu teknik memerangkap senyawa padat, cair atau gas aktif ke dalam sebuah matriks atau sistem dinding polimer berukuran mikro. Penyalut atau polimer yang digunakan dalam mikroenkapsulasi disebut agen enkapsulasi (AE) (Robert \& Fredes, 2015). Beberapa jenis agen enkapsulasi antara lain; gum arabic, gom akasia, protein (whey), polisakarida seperti maltodekstrin dari padatan dekstrosa, inulin, pati jagung dan, dan polisakarida termodifikasi. Adapun metode yang dapat digunakan antara lain: spray drying, penguapan pelarut, freeze drying, koekstruksi, polimerisasi, fluidized bed, cairan superkritikal, dan koaservasi (Ozkan \& Bilek, 2014).

Pemilihan agen enkapsulasi dan metode yang tepat sangat penting untuk efisiensi enkapsulasi yang tepat.Secara umum, agen enkapsulasi yang banyak digunakan untuk menyalut pigmen adalah maltodekstrin. Maltodekstrin memiliki kemampuan untuk berikatan menyelubungi pigmen sehingga dapat mencegah kontak langsung antara pigmen dengan lingkungan dan juga meminimalisir dampak lingkungan terhadap degradasi pigmen. Teknik enkapsulasi menggunakan maltodekstrin yang dipilih adalah pembuatan emulsi dan pengeringan oven pada suhu $60^{\circ} \mathrm{C}$. Teknik ini dipilih karena peralatan yang dibutuhkan sederhana dan pengerjaannya yang mudah.Hasil dari mikroenkapsulasi berbentuk serbuk seperti yang terlihat pada Gambar 4.

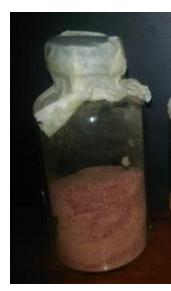

Gambar 4. Produk Pigmen Hasil Enkapsulasi

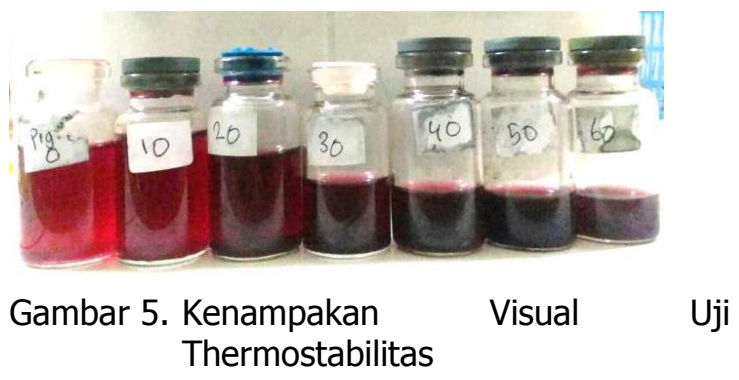




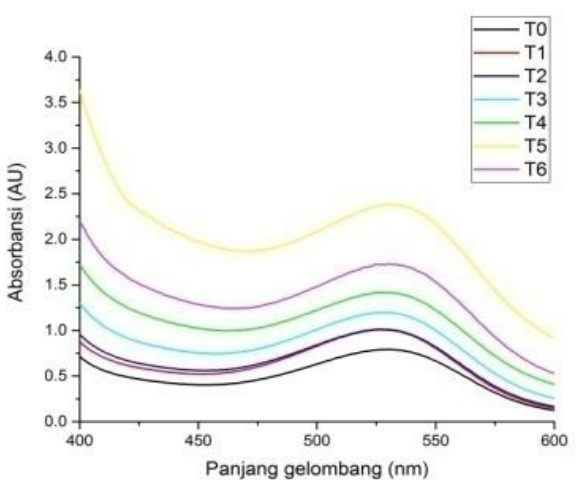

A. Pola spektra uji termostabilitas.

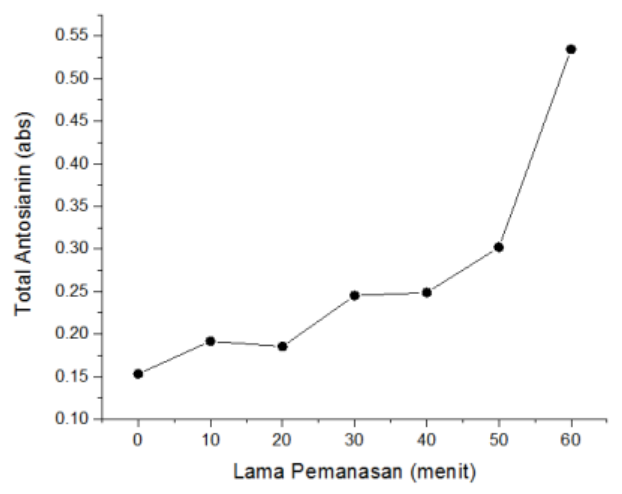

B. Grafik hubungan total antosianin (abs)terhadap lama pemanasan (menit)

Gambar 6. Pola spektra antosianin yang dipanaskan dan grafik total antosianin selama pemanasan

Tabel 2. Total antosianin dari berbagai uji petik.

\begin{tabular}{rrrr}
\hline Sampel & $\mathbf{\Lambda ~ 5 3 0}(\mathbf{n m})$ & $\mathbf{\Lambda ~ 6 5 7}(\mathbf{n m})$ & \multicolumn{1}{c}{ Antosianin $\mathbf{( m g / g )}$} \\
\hline Tanpa Pemanasan & 0.151620 & 0.008312 & 0.149542 \\
Pemanasan 10 menit & 0.190219 & 0.021113 & 0.184941 \\
Pemanasan 20 menit & 0.184281 & 0.016305 & 0.180205 \\
Pemanasan 30 menit & 0.243512 & 0.042572 & 0.232869 \\
Pemanasan 40 menit & 0.247348 & 0.034892 & 0.238625 \\
Pemanasan 50 menit & 0.299431 & 0.068732 & 0.282248 \\
Pemanasan 60 menit & 0.533187 & 0.129816 & 0.500733 \\
\hline
\end{tabular}

Pigmen alami cenderung memiliki stabilitas rendah terhadap panas. Sebagai produk pewarna untuk tambahan dalam bahan pangan, informasi tentang ketahanan terhadap paparan panas (thermostabilitas)adalah penting sebab banyak produk pangan yang diolah dengan pemanasan. Dengan adanya informasi tentang termostabilitas, dapat diketahui ketahanan pewarna terhadap suhu tinggi dan akan menjadi pertimbangan dalam proses sehingga pigmen tetap terjaga atau meminimalkan tingkat kerusakannya. Perlakuan uji yang digunakan terhadap pigmen daun miana tersalut maltodekstrin adalah menggunakan titik didih akuades yaitu $100^{\circ} \mathrm{C}$ terhadap berbagai durasi waktu.

Hasil uji pemaparan panas selama 0 60 menit dapat dilihat padagambar 6A. Terjadi peningkatan terus menerus terhadap absorbansi sampel. Kenampakan visual perubahan warna terhadap dampak pemanasan dapat dilihat pada Gambar 5. Jumlah kuantitatif konsentrasi antosianini yang diuji dengan pemaparan panas dalam sampel dituliskan dalam Tabel 2 dan grafiknya pada Gambar 6B. Pola peningkatan ini adalah pembacaan dari pola spektra yang ditunjukan pada Gambar 6A. Peningkatan bisa disebabkan oleh beberapa faktor, faktor yang pertama adalah pemanasan menyebabkan penguapan pelarut sehingga konsentrasi pigmen dalam sampel meningkat. Faktor memungkinkan yang kedua adalah adanya perngaruh dari maltodekstrin sebagai bahan penyalut pigmen. Maltodekstrin sebagai penyalut, membentuk selimut yang melindungi pigmen daripaparan panas. Panas akan terlebih dahulu mengenai maltodekstrin. Paparan panas berpengaruh terhadap daya salut maltodekstrin, pemanasan yang terus-menerus akan melemahkan ikatanikatan penyalut dan melepaskan antosianin menyebabkan terekspresinya pigmen dan meningkatnya absorbansinya. Pemaparan panas yang terus menerus menyebabkan pelarut pigmen teruapkan sehingga maltodekstrin semakin mengikat kuat pigmen, pemanasan berlanjut yang menyebabkan habisnya pelarut pigmen akan menjadikan pigmen kembali terenkapsulasi mejadi kristal.

\section{KESIMPULAN}

Daun miana dapat dijadikan sumber pigmen alami yaitu antosianin. Antosianin daun miana terekspresi dalam warna ungu. Pigmen antosianin dari daun miana dapat dienkapsulasi untuk menjaga stabilitasnya dan menghasilkan produk pigmen berupa serbuk yang berwarna. Total antosianim yang sudah dimikroenkapsulasi sebesar $0.149542 \mathrm{mg} / \mathrm{g}$. 
Pada uji termostabilitas, terjadi pola peningkatan kandungan antosianin dalam sampel. Berdasarkan hasil dan pengujian, pigmen daun miana terenkapsulasi dapat menjadi pertimbangan produk untuk digunakan sebagai bahan tambahan pewarna dalam industri pangan.

\section{DAFTAR PUSTAKA}

Anonim. 2004. Iler (Coleus scutellarioides [L] Benth).http;//www.pdpersi.co.id/?sho $\underline{\mathrm{w}}=$ detailnews\&kode $=998 \& \mathrm{tbl}=$ alterna tive, [28 Januari 2018].

Gross J. 1987. Pigment inf Fruits. Academic Press. London.

Harborne JB.1987. Metode Fitokimia Penuntun Cara Modern Menganalisis Tumbuhan. Bandung: ITB.

Hendry GAF \& Houghton JD. 1996. Natural Food Colorants. Blackie Academic \& Profesional, London.

Lestario LN, Rahayuni E, Timotius KH. 2011. Kandungan Antosianin dan Identifikasi Antosianidin dari Kulit Buah Jenitri (Elaeocarpus angustifolius Blume). AGRITECH, 31(2).

Lestario LN, Soetjipto H, Eviningyun A. 2009. Identifikasi Antosianin dan Antosianidin dari Daun Iler (Coleus scuterllariodes L. Benth) Var. Crispa dan Var. Parfivolius. Prosiding Seminar Nasional Sains dan Pendidikan Sains IV, No. 3:665-676.

Mahdavi SA, Jafari SM, Assadpoor E, Dehnnad D. 2016. Microencapsulation optimization of natural anthocyanins withmaltodekstrin, gum Arabic and gelatin Sahar. International Journal of Biological Macromolecules, (85): 379385.
Miguel MG. 2011. Anthocyanins: Antioxidant and/or anti-inflammatory activities. J of Applied Pharmaceutical Science, 01(06): 07-15.

Nguyen P, Cin VD. 2009. The role of light on foliage colour development in coleus (Solenostemonscutellarioides (L.) Codd). Plant Physiology and Biochemistry, 47(2009) 934-945.

Ozkan G, Bilek SE. 2014. Microencapsulation of natural food colourants. International Journal of Nutrition and Food Sciences, 3(3): 145-156.

Robert P, Fredes C. 2015. The Encapsulation of Anthocyanins from Berry-Type Fruits. Trends in Foods Molecules, 20: 58755888.

Suzery M, Lestari S, Cahyono B. 2010. Penentuan Total Antosianin dari Kelopak Bunga Rosela (Hibiscus sabdariffa L.) dengan Metode Maserasi dan Sokshletasi. Jurnal Sains \& Matematika, 18 (1): 1-6.

Tensiska, Nurhadi B, Isfron AF. 2012. Kestabilan Warna Kurkumin Terenkapsulasi dari Kunyit (Curcuma domestica Val.) dalam Minuman Ringan dan Jelly pada berbagai Kondisi Penyimpanan. Bionatura, 14(3):198-206.

Winarti S, Sarofa U, Anggrahini D. 2008. Ekstraksi dan Stabilitas Warna Ubi Jalar Ungu (Ipomoes batatas L.) sebagai Pewarna Alami. Jurnal Teknik Kimia, 3(1):207-14.

Zeb A \& Murkovic C. 2010. Thin-Layer Chromatographic Analysis of Carotenoids in Plant and Animal Samples. Journal of Planar Chromatography 23 2, 94-103. 